Jurnal Bisnis dan Manajemen, Volume 21, No. 2, September 2020, p. 114-128

\title{
MARKET ATTRACTION AND CAPABILITY FACTORS IN IMPROVING MARKETING PERFORMANCE THROUGH STRATEGIC DEVELOPMENT
}

\author{
Rahayu Kusumadewi ${ }^{1}$ \\ Universitas Islam Negeri Sunan Gunung Djati Bandung, Indonesia
}

\begin{abstract}
Private universities have high competition and demand to show their quality and reliable competitiveness. This research aims to analyze the attraction factor of private universities and their capabilities in supporting the development of marketing strategy and performance. This research applied a quantitative model with descriptive and verification analysis, and the used analytical tool is the SEM analysis model. The sampling technique is cluster proportional random sampling covering respondents from the stakeholders of the private university in West Java. The research findings prove that the attraction and capability factors have a significant influence on strategy, and the strategy has an effect on marketing performance, and the development of strategic planning as a strategic guideline in achieving the organization's vision and mission, which in turn can realize superior marketing performance. Moreover, this study reveals that the capacity factor has an essential influence on private universities, in particular, when paying attention to the dynamic aspects of technology and information development. Technology and information have a very significant role in realizing the superior quality of universities and can build their perceptions in the community. Another important finding is that the capacity factor has a stronger effect than the attraction factor. That is, the capability factors consisting of resources, management systems, financial strength, infrastructure support, and information technology ownership have a very strong influence in determining marketing performance.
\end{abstract}

Keywords: market attraction, capability, marketing performance, strategy

\section{FAKTOR DAYA TARIK PASAR DAN KAPABILITAS DALAM MENINGKATKAN KINERJA PEMASARAN MELALUI PENGEMBANGAN STRATEGI}

\begin{abstract}
ABSTRAK
Persaingan dan tuntutan perguruan tinggi swasta untuk menjadi perguruan tinggi yang berkualitas dan berdaya saing yang handal sangat tinggi. Penelitian ini bertujuan untuk menganalisis faktor daya tarik perguruan tinggi swasta dan kapabilitas yang dimiliki dalam mendukung pengembangan strategi dan kinerja pemasaran. Penelitian ini menggunakan model kuantitatif dengan analisis deskriptif dan verifikatif menggunakan model SEM. Teknik pengambilan sampel dilakukan secara cluster proporsional random sampling dengan target responden para pemangku kebijakan di masing-masing perguruan tinggi swasta di Jawa Barat. Hasil penelitian membuktikan bahwa faktor daya tarik dan kapabilitas berpengaruh signifikan terhadap strategi, dan strategi berpengaruh terhadap kinerja Pemasaran. Pengembangan perencanaan strategis menjadi pedoman langkah strategik dalam mencapai visi dan misi organisasi, yang pada akhirnya dapat mewujudkan kinerja pemasaran yang superior. Hasil penelitian menunjukkan bahwa peran pengembangan perencanaan strategis kedudukannya sangat penting bagi perguruan tinggi, terutama dengan memperhatikan aspek dinamika perkembangan teknologi dan informasi. Teknologi dan informasi berperan sangat penting dalam mewujudkan kualitas perguruan tinggi yang superior dan dapat membangun persepsi perguruan tinggi lebih baik di masyarakat. Penelitian ini juga mengungkapkan bahwa faktor kapabilitas memiliki pengaruh lebih kuat dibandingkan dengan faktor daya tarik. Artinya, faktor kapabilitas yang terdiri dari sumber daya, sistem pengelolaan, kekuatan finansial, dukungan infrastruktur dan kepemilikan teknologi informasi pengaruhnya sangat kuat dalam menentukan tinggi atau rendahnya kinerja pemasaran.
\end{abstract}

Kata-kata Kunci: daya tarik pasar, kapabilitas, kinerja pemasaran, strategi

\footnotetext{
${ }^{1}$ Korespondensi: Rahayu Kusumadewi, Faculty of Social and political Sciences, Universitas Islam Negeri (UIN) Sunan Gunung Djati Bandung, Jl. AH Nasution No. 105, Bandung. Email: rahayukusumadewi@uinsgd.ac.id
} 
Jurnal Bisnis dan Manajemen, Volume 21, No. 2, September 2020, p. 114-128

\section{INTRODUCTION}

The role of higher education, according to Law Number 12 of 2012, covers the development of innovative and creative academics who are competitive. Preparing graduates who have competitiveness in the industrial revolution 4.0 era is a big challenge because this requires adequate technological and information facilities to support their performance. The impact of the industrial revolution 4.0 influences not only business sectors but also the education sector, especially higher education. Therefore, this is an opportunity and a challenge for universities to have excellent competitiveness at both regional and international levels. Private universities (PTS) have a very difficult position today, it, on the one hand, must be able to create excellent graduates, and on the other hand, it must compete with state (public) universities (PTN) to attract people to study there, so that PTS is not a choice but is expected to be able to be the priority choice. The arising problem is that many PTS(s) in Indonesia are going to be closed by the Ministry of Research, Technology, and Higher Education due to their low performance. This problem also applies to West Java Province, showing that 243 PTS were closed in 2014. After gaining coaching, there were 129 PTS remained to have a performance problem, and from 129 PTS, 25 universities were officially closed in 2017 (Difta, 2017).

Today's challenge of higher education is digitization and networking, which greatly influence the process of education, research, and community service. Besides, the graduates of higher education must have sufficient capabilities in the field of technology and information. Thai, Thi, \& Anh (2017) propose that in the era of the industrial revolution, higher education institutions must update their education and training structures and systems, not only focus on hard skills but also soft skills that are in line with international standards. The greater higher education focuses on preparing graduates by developments, the better the level of competitiveness will become. Furthermore, Aryati (2019) states that the challenges of higher education are getting bigger because higher education must have the ability to master information technology that causes the demands for competence in the work field.

Some ways for higher education institutions to make changes are to be more responsive in mastering information technology, improving curriculum, quality of lecturers, and learning facilities. Consequently, higher education institutions have to fulfill all these aspects to improve their performance in the 4.0 revolution era. Achieving superior performance requires effective and flexible strategic planning with changes and developments in the existing environment (Neil, 2011). This means that strategy is an alternative solution to solving problems and finding new opportunities. The role of strategy is critical to achieving the fixed goals and objectives of the organization. 
Jurnal Bisnis dan Manajemen, Volume 21, No. 2, September 2020, p. 114-128

Organizations or companies will find difficulties in achieving organizational goals without implementing the planned strategy (Thomas L. Wheleen and J. David Hunger, 2010). Some research findings have proven the critical role of the strategy to the organization. Each of the following studies (Agwu, 2018; Liao \& Huang, 2016; Okeke, Onuorah, \& Jakpa, 2016) proved that the strategy has a positive effect on performance, so that strategy has a crucial position to improve performance. The research conducted by Hajar (2015) showed that the strategy directly affects not only performance but also innovation.

The success of strategic planning in higher education is strongly determined by the level of strategy suitability to environmental change. The external environment of higher education institutions is a strategic environment where competencies continue to occur and cannot be stopped (Mirfani, Sutarsih, \& Rosalin, 2017), while their internal environment is a component from which the ability of organization originates to deal with changes in the organizational environment (Nofrizal, 2018). External environment analysis is intended to identify opportunities and threats factors and to face changes in the increasingly dynamic external environment, while the internal environment analysis aims to analyze and map the capabilities and weaknesses by their resources (Gunawan, Alhabsji \& Rahardjo, 2014). The less capability of higher education institutions to make analysis and quick adjustment to changes in the external and internal environment can reduce performance. Many factors of the external environment influence strategy planning, one of which is market attraction. In marketing management, market attraction depends on the company's ability to produce consumers who are willing to buy their products (Almgren, 2014).

Like buying a product, prospective students choose universities with market attraction factors that provide added value and have reliable capabilities. The attraction that is accompanied by capability will be a driving factor in the development of conduct strategies to improve marketing performance that has higher quality because, in the industrial revolution 4.0 era, the quantity factor of higher education is no longer the primary benchmark in achieving success, but lies in the quality of graduates who have competitive skills.

This study will examine the factors of attraction and capability in supporting strategy development and its impact on marketing performance. Based on the previous research results, there was no testing model of market attraction and capability to the strategy development and its impact on marketing performance. Two previous studies (Ismiyati, 2011; Nalim, 2012) dealt with attraction factor in state universities, while this present research is carried out in private universities that have independent management. The subsequent 
Jurnal Bisnis dan Manajemen, Volume 21, No. 2, September 2020, p. 114-128

research was carried out (Solihat, 2011) by one who did the capability factor study in influencing competitive advantage, whereas the following study will examine the effect of strategy development. Subsequent research conducted earlier (Chandler \& Hanks, 1994; Sipayung, Sucherly, Affif, \& Soemaryani, 2016) examined the attraction and capability factor models for business strategies. Those studies focus on strategy development and its impact on higher education performance. Based on normative, theoretical, and empirical foundations, this present study will conduct a study of attraction and capability factors on strategy development and their impact on marketing performance.

\section{LITERATURE REVIEW}

\section{Market Attraction}

When applied to higher education institutions, the attraction concept becomes a very essential and decisive factor in deciding whether to choose a higher education institution or not (Iriani, 2010; Ismiyati, 2011). The attraction factor is a determinant factor on which a prospective student determines his choice (Nalim, 2012). According to National Accreditation Board for Higher Education (BAN-PT) the attraction aspects of evaluation in determining the assessment of the quality of higher education cover curriculum, teacher qualifications, student anatomy, education process and teaching, infrastructure, academic administration, personnel, financial administration, and internal organizations that support educational activities. In other words, it can be said that market attraction is a resource in determining choices.

\section{Capability}

According to Amir (2011), a capability is an ability to utilize the resources within an organization and explore all the potential to carry out a series of activities. Capability is a combination of tangible and intangible aspects that are used to convert inputs into outputs (Budiastuti, 2011). The best defense in a highly competitive environment is by having the capability to face time and technology. A capability that is considered to be a skill in improving performance capacity is a capability that is oriented towards the use of technology and information (Sidiq, 2017).

\section{Strategy Development}

Strategy planning is defined as an effort to make decisions with the full discipline to guide the steps that need to be carried out in the future time (Bass \& Avolio, 2011). Strategy planning needs to be developed in its implementation to make it easier to answer challenges and minimize obstacles in the future (Syahrul, 2017). Strategy planning is seen to be very meaningful for the organization to be a reference in describing the goals of the organization in the short term as well as a guide in carrying out 
Jurnal Bisnis dan Manajemen, Volume 21, No. 2, September 2020, p. 114-128

activities according to the agreement to achieve the specified goals (Rusniati \& Ahsanul Haq, 2014).

\section{Marketing Performance}

Performance is defined to be an achievement resulted from the process or behavior of higher education institutions, which is expected to be able to produce a good output (Kurniawan, Purwito \& Nurani, 2016). To achieve good performance, it is necessary to do strategic planning by identifying external and internal environmental factors (Nurhapna, Haksama, \& Kadri). The resulted performance is a manifestation of the extent to which strategic planning is implemented (Sunarmie, 2011). That is, good performance results from good strategy planning together with increasing sources of intensity so that they can achieve maximum results. Marketing performance in this research is a concept to measure the extent of the market performance of a product or given service.

\section{Hypothesis Development}

The attraction factors of higher education cover academic quality, academic standardization, location of higher education, graduate competence, tuition fees, the progress of accreditation, and the presence of outsider students (Ismiyati, 2011), while the research results of Faizah (2016) show that the factors of external attraction include prospect and opportunity factors, as well as study program factors. The research results of Ruhiyat (2013) prove that aspects of facilities, curriculum, and accreditation become the highest rank of attraction factor. Moreover, Sukaris (2018) states that the characteristics of each segmentation must have an attraction because in the future time the sustainability of higher education institutions depends on how much higher education institutions can build differences and excellence. The results of research Gleißner (2013) empirically prove that market attraction is an essential factor in strategy control. In addition to the attraction, the capability factor needs to be considered in determining strategic direction. In this regard, Rogério dos Santos Alves (2014) states that capability is the core of the strategy that needs to be integrated with technology for developing a company's competitiveness. Dynamic capability is the key to implementing effective strategies for realizing a world-class university (Suyono, 2018).

As a result, building a reliable strategy to improve competitive performance needs to be done by considering the attractiveness and capability factors. The research results of Sipayung (2016) prove that attraction and capability factors contribute to building strategy. While the study of Muhammad (2016) shows that the attraction and capability factors have a positive effect on performance, although the effect is not too significant. Here is the conceptual diagram of this research. Figure 1 on 
Jurnal Bisnis dan Manajemen, Volume 21, No. 2, September 2020, p. 114-128

the research paradigm stated that the hypotheses

of this study are market attraction and capability have a simultaneous and partial effect on strategy development. Another hypothesis is that strategy development affects marketing performance.

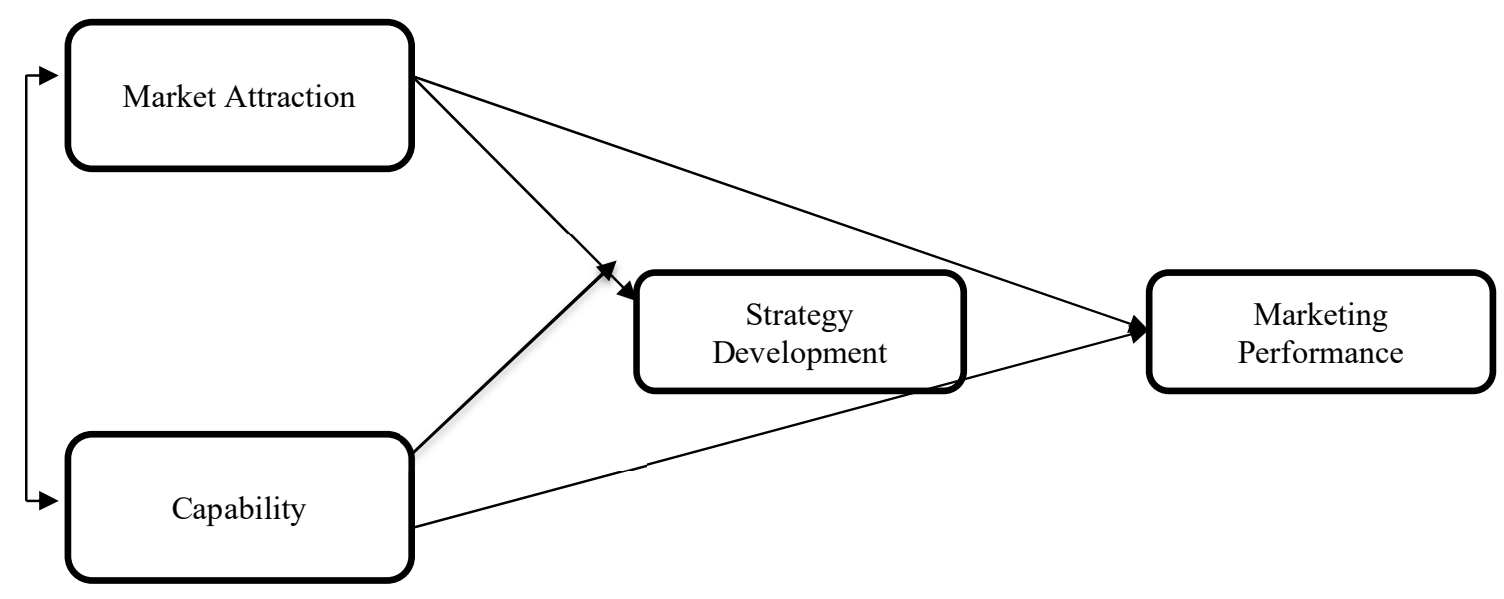

Figure 1. Research Paradigm

\section{METHODS}

This research elaborates on marketing management, especially the development of strategies in improving marketing performance to meet competition. The input factors in this study cover attraction and capability factors, while the intervening factor is the development of strategy, and the output variable is marketing performance. This research is quantitative with descriptive and verification analysis. The data source of this study includes primary data which is relating to the research questionnaire, while secondary data covers documentation data. This research was conducted at PTS in the region IV of West Java and Banten due to the high growth rate of higher education institutions in West Java and Banten Provinces. However, the collapse of several PTS attracted the researcher's interest to conduct further research.

The number of samples, which consists of 211 PTS around the province of West Java is analyzed by Slovin's formula. The sampling technique is done by cluster proportional random sampling. Furthermore, the data was collected through questionnaires and interviews.

The questionnaire question model was conducted with closed questions using a Likert scale, and the respondents covered university leaders or faculty deans representing the strategic planning team. In contrast, the interview method was conducted with open questions conducted to university leaders or those representing the strategic planning team. Before data analysis, the questionnaire data is first tested for its validity and reliability so that 
Jurnal Bisnis dan Manajemen, Volume 21, No. 2, September 2020, p. 114-128

the instruments have accuracy and reliability.

The technique of data analysis is Structural Equation Modeling (SEM) analysis. The basis for taking SEM is that this research enables the researcher to apply SEM analysis.

\section{RESULTS AND DISCUSSION}

SEM analysis is aimed to analyze the measurement model and structural model to determine the effect of market attraction, capability on the implementation of PTS strategies, and their impact on college performance.

The initial stage of SEM analysis is testing the suitability of the model (Goodness-of-fit). The testings of validity and reliability in SEM analysis in this study were applied to construct reliability and variance extracted. Ghozali (2013) revealed that the indicator of the variable is regarded valid if the "Estimate" value is > 0.05 , and regarding reliability, the indicator of the variable is regarded as reliable if the CR value is $\geq 0.07$. The results of the validity and reliability testing can be seen in table 1 .
Table 1. Validity and Reliability

\begin{tabular}{|c|c|c|c|c|}
\hline No & Indicator & $\begin{array}{c}\text { Standardized } \\
\text { Estimate }\end{array}$ & $\begin{array}{l}\text { Construct } \\
\text { Reliability } \\
\end{array}$ & $\begin{array}{l}\text { Variance } \\
\text { Extracted }\end{array}$ \\
\hline 1 & $\begin{array}{l}\text { Study } \\
\text { program } \\
\left(\mathrm{X}_{1.1}\right)\end{array}$ & 0.649 & \multirow[t]{3}{*}{0.709} & \multirow[t]{3}{*}{0.762} \\
\hline 2 & $\begin{array}{l}\text { Accreditation } \\
\left(\mathrm{X}_{1.7}\right)\end{array}$ & 0.762 & & \\
\hline 3 & Image $\left(\mathrm{X}_{1.8}\right)$ & 0.612 & & \\
\hline 4 & $\begin{array}{l}\text { Human } \\
\text { resources } \\
\left(\mathrm{X}_{2.2)}\right.\end{array}$ & 0.536 & \multirow{3}{*}{0.701} & \multirow{3}{*}{0.512} \\
\hline 5 & $\begin{array}{l}\text { Financial } \\
\left(\mathrm{X}_{2.3}\right)\end{array}$ & 0.603 & & \\
\hline 6 & $\begin{array}{l}\text { Technology } \\
\text { ownership } \\
\left(\mathrm{X}_{2.5}\right)\end{array}$ & 0.729 & & \\
\hline 7 & $\begin{array}{l}\text { Target setting } \\
\left(\mathrm{Y}_{1}\right)\end{array}$ & 0.540 & \multirow{4}{*}{0.711} & \multirow{4}{*}{0.642} \\
\hline 8 & $\begin{array}{l}\text { Institutional } \\
\text { development } \\
\left(\mathrm{Y}_{6}\right)\end{array}$ & 0.611 & & \\
\hline 9 & $\begin{array}{l}\text { Independent } \\
\text { capability } \\
\text { development } \\
\left(\mathrm{Y}_{7}\right)\end{array}$ & 0.672 & & \\
\hline 10 & $\begin{array}{l}\text { Strengthening } \\
\text { organizational } \\
\text { integrity }\left(\mathrm{Y}_{11}\right)\end{array}$ & 0.559 & & \\
\hline 11 & $\begin{array}{l}\text { Graduates } \\
\left(Z_{1}\right)\end{array}$ & 0.637 & \multirow{4}{*}{0.746} & \multirow{4}{*}{0.773} \\
\hline 12 & Research $\left(Z_{2}\right)$ & 0.647 & & \\
\hline 13 & $\begin{array}{l}\text { Curriculum } \\
\left(Z_{3}\right)\end{array}$ & 0.574 & & \\
\hline 14 & $\begin{array}{l}\text { Academic } \\
\left(\mathrm{Z}_{4}\right)\end{array}$ & 0.554 & & \\
\hline
\end{tabular}

Source: Analysis result

The calculation results show that 14 indicators are regarded as valid and reliable. The results of validity testing state that the 14 indicators have a Standardized Estimate value> 0.05 , so it is assumed that all indicators have good enough validity. Moreover, the results of reliability testing of the market attraction variable have a construct reliability value of 0.709 , capability of 0.701 , and strategic planning development of 0.711 and university performance of 0.746 . 
Jurnal Bisnis dan Manajemen, Volume 21, No. 2, September 2020, p. 114-128

Because the construct reliability value of the five variables is greater than the cut-off value of 0.7 , the indicators have good internal consistency. Moreover, regarding the variance extracted value, the market capability variable has a value of 0.761 , a capability value of 0.512 , a strategic planning development value of 0.642 , and a performance value of 0.773 . So, the extracted variance value will be smaller than the construct reliability value. Because the five variables get the extracted variable value $>0.50$, the extracted variance from the indicators is greater for the formation of latent variables.

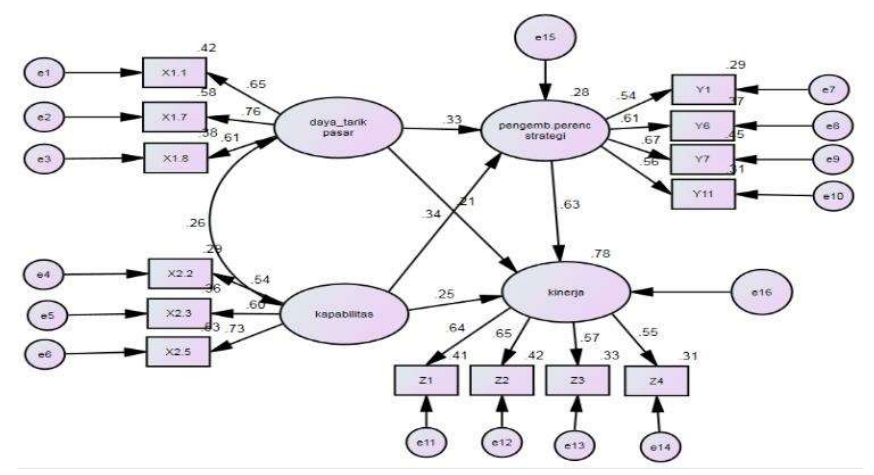

Figure 2. SEM Analysis Result

Source: Analysis result

Figure 2 shows the results of the structural model analysis as a whole. It can be seen that not all indicators play a significant role in each variable. From 31 indicators studied, only 14 indicators are considered very dominant to shape each variable, while the other indicators get system drop because these indicators do not play a role in maximizing the research model performance after the process of SEM analysis. Based on the research results, the indicators that play a dominant role in forming the attraction of higher education institutions in West Java Province cover study program, accreditation, and image of higher education institutions. Moreover, the indicators that play a dominant role in shaping capabilities include human resources, financial resources, and technology ownership. Regarding the variable of strategic planning development, the indicators of target setting, institutional development, and independent capability development are components that play a very dominant role in developing strategic planning. And for the marketing performance variable of higher education, graduate's quality, research, curriculum, and academics are seen to be dominant variables.

\section{Table 2. Feasibility Testing of Research} Model

\begin{tabular}{lccc}
\hline $\begin{array}{c}\text { The goodness of fit } \\
\text { index }\end{array}$ & $\begin{array}{c}\text { Cut of } \\
\text { Value }\end{array}$ & Result & Decision \\
\hline$\chi 2-$ Chi-square & $<91.670$ & 76.391 & Good \\
Significance & $\geq 0.05$ & 0.310 & Good \\
probability & & & \\
RMSEA & $\leq 0.08$ & 0.019 & Good \\
GFI & $\geq 0.90$ & 0.952 & Good \\
AGFI & $\geq 0.90$ & 0.929 & Good \\
CMIN/DF & $\leq 02.0$ & 1.076 & Good \\
TLI & $\geq 0.95$ & 0.989 & Good \\
CFI & $\geq 0.95$ & 0.991 & Good \\
\hline SOUr
\end{tabular}

Source: Analysis result

Table 2 reveals that the feasibility testing of the SEM model applied Chi-square, CFI, TLI, CMIN / DF, RMSEA, GFI, and AGFI in the range of expected values. The testing results indicate that the model is acceptable. The significance level of 0.310 shows a very good 
Jurnal Bisnis dan Manajemen, Volume 21, No. 2, September 2020, p. 114-128

structural equation model. The measurement indexes of TLI, CFI, CMIN / DF, GFI, AGFI, and RMSEA are covered in the expected value range. In consequence, the feasibility testing of the SEM model meets the acceptance requirements.

Table 3. Research Hypothesis Testing

\begin{tabular}{|c|c|c|c|c|c|c|c|c|}
\hline & & & & Estimation & SE. & CR. & $\mathbf{P}$ & Result \\
\hline $\begin{array}{l}\text { Strategic planning } \\
\text { development }\end{array}$ & $<--$ & Market attraction & .253 & & .087 & 2.897 & .004 & accepted \\
\hline $\begin{array}{l}\text { Strategic planning } \\
\text { development }\end{array}$ & $<--$ & Capability & .317 & & .104 & 3.061 & .002 & accepted \\
\hline $\begin{array}{l}\text { Marketing } \\
\text { performance }\end{array}$ & $<--$ & $\begin{array}{l}\text { Strategic planning } \\
\text { development }\end{array}$ & .657 & & .150 & 4.375 & $* * *$ & accepted \\
\hline $\begin{array}{l}\text { Marketing } \\
\text { performance }\end{array}$ & $<--$ & Capability & .246 & & .103 & 2.388 & .017 & accepted \\
\hline $\begin{array}{l}\text { Marketing } \\
\text { performance }\end{array}$ & $<--$ & Market attraction & .168 & & .079 & 2.134 & .033 & accepted \\
\hline
\end{tabular}

Source: Analysis result

Table 3 shows that the path between attraction and strategic planning development has CR (Critical Ratio) value of 2,897 > 1,960. Thereby market attraction has a positive and significant influence on the development of strategic planning, the path between capability variable and strategic planning development has CR value of $3,061>1,960$. Thus, the capability has a positive and significant effect on strategic planning development. The path between strategic planning development and performance has a CR value of 4,375 > 1,960. Thus, strategic planning development has a positive and significant effect on performance. The path between capability and performance variables has a CR value of $2,388>1,960$. Thus, the capability has a positive and significant effect on performance. The path between market attraction and performance has a $\mathrm{CR}$ value of $2.134>1,960$. Therefore, the market attraction has a positive and significant effect on performance. The data below explains the magnitude of the direct, indirect, and total effects of SEM analysis results on the research model.

Table 4. Direct, Indirect and Total Effects

\begin{tabular}{|c|c|c|c|c|}
\hline & & $\begin{array}{l}\text { Direct } \\
\text { Effect }\end{array}$ & Indirect & $\begin{array}{l}\text { Total } \\
\text { Effect }\end{array}$ \\
\hline Attraction & $\begin{array}{l}\text { Strategic } \\
\text { planning } \\
\text { development }\end{array}$ & 0.333 & - & 0.333 \\
\hline Attraction & $\begin{array}{l}\text { Marketing } \\
\text { performance }\end{array}$ & 0.212 & 0.210 & 0.422 \\
\hline Capability & $\begin{array}{l}\text { strategic } \\
\text { planning } \\
\text { development }\end{array}$ & 0.336 & - & 0.336 \\
\hline Capability & $\begin{array}{l}\text { Marketing } \\
\text { performance }\end{array}$ & 0.250 & 0.212 & 0.462 \\
\hline $\begin{array}{l}\text { Strategic } \\
\text { planning } \\
\text { development }\end{array}$ & $\begin{array}{l}\text { Marketing } \\
\text { performance }\end{array}$ & 0.631 & - & 0.631 \\
\hline
\end{tabular}

Source: Analysis result

Table 4 reveals that the effect of market attraction is more influential on strategic planning development compared to capability. The total effect of attraction on strategic 
Jurnal Bisnis dan Manajemen, Volume 21, No. 2, September 2020, p. 114-128

planning development is 0.333 , while the total effect of capability on strategic planning development is 0.336. However, the variable capability is more influential on performance when compared to market attraction. The value of capability effect on performance is 0.462 directly and indirectly. The results of this study indicate that market attraction and capability factors each have advantages and disadvantages to influence endogenous variables (strategic planning development and performance). Nevertheless, the two variables have shown results that market attraction and capability have an effect on strategic planning development and positive and significant effects on performance. This result supports some previous studies, such as the findings of the research (Adam, Syahputra, \& Gunawan, 2016), stating that attraction affects strategy formulation and performance implications as well. The attraction factor has a very high impact, so every company must consider industrial attraction to achieve high performance.

This study shows that strategic planning development is strongly affected by the market attraction of 0.336 . The market attraction factor in this study is related to the study program, accreditation, and image of high education institutions, while capability is related to technology ownership. The indicator of technology in terms of information technology development covers internet facilities, academic and administrative systems that have used a digitizing system supported by adequate software and hardware by universities, and is crucial in developing future strategic planning.

The results of this study support the research conducted by (Varnali, 2011), proposing that technology and information in the form of internet facilities are seen to be an important component and have a significant effect on the company's strategy in attracting customer interest. In this study, the capability influences strategy and direct effect on performance by 0.223 . This result indicates that capability has a direct effect on performance without strategic planning.

The capability in this study reflects all aspects of capability resources, as dominant indicators such as human resources, finance, and technology ownership. Moreover, this study supports the results of previous studies, empirically confirming that capabilities directly influence performance (Mait, 2014); (Zhou, Zhou, Feng, \& Jiang, 2017). Capability in this study is more dominated by the role of higher education institutions in developing communication and information technology to become superior resources in organizations. Finally, this study gives support to the research findings of Namusonge, Mukulu, Iravo, Lecturer, \& Kenyatta (2016), stating that communication and information technology have become an essential factor in the company because they have proven to have a direct effect on performance. 
Jurnal Bisnis dan Manajemen, Volume 21, No. 2, September 2020, p. 114-128

The research findings indicate that strategic planning development has a significant effect on performance improvement with a value of 0.631 . This shows that the strategy is a guideline that is considered sufficient for each organization because the high or low marketing performance can be determined by an integrated strategic planning system by utilizing all the strengths and opportunities by paying attention to weaknesses and threats. Therefore, the strategic planning that has been formulated in its implementation needs to be developed by the existing level of development.

Developing strategic planning is believed to be essential for organizations, as it can improve that strategic planning that is more flexible in dealing with a dynamic environment when compared with stagnant strategic planning. Furthermore, the development and adaptation strategies to current environmental conditions are more effective and efficient because, according to the indicator of independent capacity development, they have a value of 0.67 . The indicator is believed to be the highest indicator in shaping the variable of strategic planning development. Besides, this study supports the findings of previous studies, which show that strategy empirically has a positive and significant effect on performance (Anwar, Shah, \& Hasnu, 2016); (Ray, 2004); (Njenga \& Gachunga, 2016).

\section{CONCLUSION}

The market attraction is formed by the following indicators: study program, academic standards, location, job opportunity, activity, cost, accreditation, and image. Based on Confirmatory Factor Analysis, it was stated that the dominant indicators to shape market attraction covered study programs, accreditation, and the image of higher education institutions. Meanwhile, the capability is formed by the indicators of implementation, human resources, finance, infrastructure, and information technology.

Confirmatory Factor Analysis reveals that the dominant indicators in shaping capabilities include human resources, finance, and technology ownership. Strategic planning development is formed by the indicators of target setting, capacity development, culture development based on performance, expansion of the ability to apply the principle of equal rights, institutional development, independent capacity development, administrative and academic principles development, of quality assurance systems development, climate development, and entrepreneurial ability, strengthening organizational integrity and learning capability development. Furthermore, Confirmatory Factor Analysis states that the dominant indicators to form strategic planning development cover goal setting, institutional development, independent capacity building, and strengthening organizational integrity. 
Jurnal Bisnis dan Manajemen, Volume 21, No. 2, September 2020, p. 114-128

Marketing performance is shaped by the indicators of graduates, research, community service, curriculum, internal, and academic quality assurance.

Meanwhile, the dominant indicators in shaping marketing performance consist of graduate's quality, research, curriculum, and academics. Market attraction and capabilities simultaneously and partially have positive and significant effects on strategic planning development. Besides, market attraction and capabilities simultaneously and partially have positive and significant effects on marketing performance, and the development of strategies has a positive and significant effect on marketing performance too.

Marketing performance in the industrial revolution 4.0 era, which is based on the research findings, indicates that the excellent university with superior graduates and science and technology mastery is the institution that can follow the development of the industrial revolution 4.0. The second finding is that university with good marketing performance in the era of industrial revolution 4.0 can respond to the challenges and dynamics of the environment, primarily related to the impact of the industrial revolution 4.0.

The next finding shows that higher education institution that can demonstrate its marketing performance is the university that can balance curriculum and academics, namely the one that implements Curriculum-Based
Indonesian National Qualification Framework (KKNI) elaborated with the demands of technological development so that the final result can provide graduates with higher quality output, independence, and competitiveness of their scientific disciplines and specific expertise by the demands of the times. Therefore, private universities in region IV West Java and Banten which have a big student body are expected to consider marketing performance in the industrial revolution 4.0 era which is based on 4 factors: quality of graduates, research, curriculum, and academics. The four factors are the key to attract the interest of prospective students in determining their choices.

This research empirically proves that the attraction and capability factors have partial and simultaneous influence both on strategy development. This indicates that the organization can perform strategy development by taking into account internal and external aspects. One of the internal aspects is capability, especially in terms of technological and financial capability and human resources. Meanwhile, external aspects are related to attraction factors, which are shown in the accreditation assessment in the sight of the public and the existing image of universities. Paying serious attention to these two aspects is very important to formulate and plan the development of more effective and efficient strategies. The development of empirical strategic planning can improve marketing 
Jurnal Bisnis dan Manajemen, Volume 21, No. 2, September 2020, p. 114-128

performance; this shows that the marketing performance of universities in the form of service outputs, namely the quality of graduates, research, curriculum, and academic systems, is seen to be the core business of the university, which requires effective and efficient strategy planning in its achievement.

Theoretically, the research model developed by researchers is expected to reinforce the theory that attraction as an external factor and capability as an internal factor has a significant effect on the development of strategic planning. Through the development of strategic planning that serves as a guideline in achieving the vision and mission of the organization, it is hoped that an organization can realize superior marketing performance.

Managerial implications of this study indicate that developing strategic planning has a crucial position in higher education institutions, especially by paying attention to the dynamics of technology and information development. Technology and information have significant roles in higher education institutions because by mastering technology and information, the institutions can survive in the tight competition.

\section{LIMITATION AND SUGGESTION}

This research is limited to private universities in West Java Province with limited respondents from university leaders, faculty deans, or strategic planning teams involved in the private higher education institutions. Also, the limitation of this study is regarding research units that are only focused on private universities, beyond the specialized and academic colleges. The next restriction lies in the non-random sampling applied so that not all elements in higher education have the same opportunity to be sampled in this study. The final limitation is the capability variable, which is still too general.

Based on the research conclusions, it is expected that further research will include broader fields of study at universities and specialized and academic colleges. The further suggestion in the next study is regarding respondents that can cover not only university leaders, faculty deans, or strategic planning teams but also lecturers. Regarding capability variables that are still general, it is better than in future studies the capability variables are more focused on innovation capabilities that are comprehensively studied, considering the capability of universities to innovate technology and information application in the academic climate will change the development order strategy done by each university or college.

\section{REFERENCES}

Adam, M., Syahputra, H., \& Gunawan, B. (2016). Industry Attractiveness and Knowledge Management on the Formulation of Competitive Strategy and Parternership and Its Implication on Coffee Company Performace in Aceh. (Isclo), 204-210. https://doi.org/10.2991/isclo15.2016 .38

Agwu, M. E. (2018). Analysis of the impact of strategic management on the business performance of SMEs in Nigeria. Academy of 
Jurnal Bisnis dan Manajemen, Volume 21, No. 2, September 2020, p. 114-128

Strategic Management Journal, 17(1), 1-20.

Almgren, K. (2014). The Four Factors for Targeting an Attractive Market. International Journal of Humanities and Social Science, 4(91), 71-76. Retrieved from http://www.ijhssnet.com/journals/Vol_4_No_9_1 _July_2014/9.pdf

Anwar, J., Shah, S., \& Hasnu, S. (2016). Business Strategy and Organizational Performance : Measures and Relationships. Pakistan Economic and Social Review, 54(1), 97-122.

Aryati, S. (2019). Tantangan Perguruan Tinggi Di Era Revolusi Industri 4.0. Prosiding Nasional, 811818.

Bass, B. \& Avolio, B. (2011). Full range leadership development: Manual for multifactor leadership questionnaire. Redwood City, California: Mind Garden.

Budiastuti, D. (2011). KOMPETITIF DAN DAMPAKNYA TERHADAP KINERJA PERUSAHAAN PADA PT ADI CIPTA , MAKASSAR. Binus Bussines Review, 2(1), 286292.

Chandler, G. N., \& Hanks, S. H. (1994). Market Attractiveness, Resource-Based Capabilities, Venture Strategies, And Venture Performance. Journal of Business Venturing, 9(4), 331-349. https://doi.org/https://doi.org/10.1016/08839026(94)90011-6

Difta, S. (2017). 102 Perguruan Tinggi Swasta Terancam Ditutup. Pikiran Rakyat.

Faizah, A. (2016). Faktor-Faktor Yang Mempengaruhi Minat Mahasiswa Memilih Effecting Factor of Student Interest To Study in Music Art Education. Jurnal Pendidikan Dan Seni Musik, 8, $1-7$.

Gleißner, W., Helm, R., \& Kreiter, S. (2013). Measurement Of Competitive Advantages And Market Attractiveness For Strategic Controlling. Journal of Management Control, 24(1), 53-75. https://doi.org/10.1007/s00187-013-0167-1

Gunawan, D. S., Alhabsji, T., \& Rahardjo, K. (2014). Analisis Lingkungan Eksternal dan Internal Dalam Menyusun Strategi Perusahaan ( Studi Perencanaan Strategi Komoditi Kelapa Sawit. 22-33.

Hajar, I. (2015). The Effect of Business Strategy on Innovation and Firm Performance in the Small Industrial Sector. The International Journal of Engineering and Science, 4(2), 1-9. Retrieved from www.theijes.com

Iriani, Y. (2010). Analisis Faktor-Faktor Yang Mempengaruhi Minat Studi Mahasiswa Dalam Menempuh Pendidikan di Universitas
Widyatama. Proceeding Seminar Nasional IV Manajemen Dan Rekayasa Kualitas, 532-541.

Ismiyati. (2011). Faktor Daya Tarik dan Kinerja Pelayanan Menurut Persepsi Mahasiswa: Studi FE UNNES. Jurnal Pendidikan Ekonomi Dinamika Pendidikan, VI(2), 170-187.

Kurniawan, Y., Purwito, A., \& Nurani, T. W. (2016). Pencapaian Indikator Kinerja Bidang Akademik Program Sarjana Pada Fakultas Perikanan Dan Ilmu Kelautan Institut Pertanian Bogor Dalam Perspektif Penjaminan Mutu. Jurnal Aplikasi Bisnis Dan Manajemen (JABM), 2(3), 258.

Liao, K.-H., \& Huang, I.-S. (2016). Impact of Vision, Strategy, and Human Resource on Nonprofit Organization Service Performance. Procedia Social and Behavioral Sciences, 224(August 2015), $20-27$. https://doi.org/10.1016/j.sbspro.2016.05.395

Mait, R. (2014). The impact of capabilities on performance. 114(2), 241-257.

Mirfani, A. M., Sutarsih, C., \& Rosalin, E. (2017). Strategi dan Hasil Kompetisi Perguruan Tinggi. Jurnal Administrasi Pendidikan, 14(1), 182-197.

Muhammad, Ade Sulchi, Dwi Kartini, W. O. Z. M. and E. F. (2016). the Influence of Industry Competitive Forces and Distinctive Capabilities on Competitiveness and the Implication on the Performance of. IV(10), 262-278.

Nalim. (2012). Analisis Faktor yang Memengaruhi Mahasiswa dalam Memilih Program Studi Pendidikan Bahasa Arab STAIN Pekalongan. Forum Tarbiyah, 10(2), 215-235.

Namusonge, E., Mukulu, E., Iravo, M., Lecturer, S., \& Kenyatta, J. (2016). Influence of Information Communication Technology (ICT) Capabilities on Firm Performance of Manufacturing Entities in Kenya. International Journal of Management and Commerce Innovations, 4(2), 847-855. Retrieved from www.researchpublish.com

Neil, R. (2011). Strategic management. In Workplace Strategies and Facilities Management. https://doi.org/10.4324/9780080521299

Njenga, M. W., \& Gachunga, H. (2016). Effects of Change Management Strategy on Performance in Public Universities in Kenya, The Case of The Technical University of Kenya Effects of Change Management Strategy on Performance in Public Universities in Kenya. Journal of Business and Change Management, 3(2), 596-625.

Nofrizal, N. (2018). Analisis Swot Untuk Menentukan Posisi Strategis Pada Universitas Lancang Kuning Pekanbaru. Economica, 7(1), 40-53. https://doi.org/10.22202/economica.2018.v7.i1.2 637 
Jurnal Bisnis dan Manajemen, Volume 21, No. 2, September 2020, p. 114-128

Okeke, M. N., Onuorah, A. N., \& Jakpa, U. G. (2016). Impact of Strategic Management on the Performance of Small and. Global Journal of Applied, Management and Social Sciences, 11(2), $57-66$.

Ray, S. (2004). Environment-Strategy-Performance Linkages: A Study of Indian Firms during Economic Liberalization. 29(2), 9-23.

Rogério dos Santos Alves; Alex Soares de Souza, et all. (2014). The Management of Technology and Innovation. In South-Western Cengage Learning. https://doi.org/10.1007/s13398-014-0173-7.2

Ruhiyat, E. (2013). Analisis faktor yang menjadi penentu mahasiswa dalam memilih perguruan tinggi. Jurnal Ilmiah Ilmu Manajemen, 78-96.

Rusniati \& Ahsanul Haq. (2014). Perencanaan Strategis dalam Perspektif Organisasi. Jurnal INTEKNA, (2), 77-78.

Sidiq, A. (2017). Analisis Kapabilitas Teknologi Informasi terhadap Kinerja Bisnis UKM dengan Orientasi Pelanggan sebagai Variabel Intervening (Studi pada UKM Sektor Manufaktur di Wilayah Solo Raya). Media Ekonomi Dan Manajemen, 32(1), 9-27.

Sipayung, R. I. M., Sucherly, Affif, A., \& Soemaryani, I. (2016). The Influence Of Business Partnership And Competitive Strategy On Business Performance Of Recreation Park Services Industry In West Java, Indonesia. South East Asia Journal of Contemporary Business, Economics and Law, 11(02), 109-115.

Solihat, A. (2011). Pengaruh Sumber Daya dan Kapabilitas terhadap Keunggulan Posisi :Survei pada Program Studi Manajemen di Perguruan Tinggi Kota/Kabupaten Bandung. Universitas Pendidikan Indonesia.
Sukaris. (2018). Kajian Empiris dalam Pemosisian Produk( Studi pada Perguruan Tinggi ). JRE: Jurnal Riset Entrepreneurship, 1(2), 1-12.

Sunarmie. (2011). Analisis Pengaruh Kompetensi Manajerial, Dinamika Lingkungan, dan Dukungan Organisasi terhadap Kualitas Perencanaan Strategik Perguruan Tinggi Swasta di Koordinasi Perguruan Tinggi Swasta Wilayah XI. 1-18.

Suyono. (2018). Dynamic Capability Sebagai Strategi Menuju World Class University. Seminar Dan Call for Paper Sustainable Competitive Advantage (SCA) 8 Purwokerto, 19 September 2018, (September), 1-13.

Syahrul. (2017). Perencanaan Strategis dan Praktik .... Shautut Tarbiyah, 36, 1-18.

Thai, H. Van, Thi, L., \& Anh, K. (2017). the 4.0 Industrial Revolution Affecting Higher Education Organizations' Operation in Vietnam. International Journal of Management Technology, 4(2), 1-12.

Thomas L. Wheleen and J. David Hunger. (2010). Strategic Management and Business Policy Achieving Sustainability International Edition (Internatio; E. Svendsen, Ed.). New: PrenticeHall.

Varnali, K. (2011). The Impact of the Internet on Marketing Strategy. International Journal of $E$ Business Research, 6(4), 38-51. https://doi.org/10.4018/jebr.2010100104

Zhou, S. S., Zhou, A. J., Feng, J., \& Jiang, S. (2017). Dynamic capabilities and organizational performance: The mediating role of innovation. Journal of Management and Organization, 1-17. https://doi.org/10.1017/jmo.2017.20 